\title{
The effect of a surgical smoke evacuation system on surgical site infections of the spine
}

\author{
Steven Krueger ${ }^{1}$, Steve Disegna ${ }^{2}$ and Christian DiPaola ${ }^{3 *}$ \\ ${ }^{1}$ University of Massachusetts Medical School, USA \\ ${ }^{2}$ Department of Orthopedics \& Rehabilitation, University of Massachusetts Medical School, USA \\ ${ }^{3}$ Department of Orthopedics \& Rehabilitation, University of Massachusetts Medical School, USA
}

\begin{abstract}
Objectives: To review the literature on surgical smoke and to study the effect of a smoke evacuation system on the rate of surgical site infections (SSIs) after spine surgery.

Introduction: Surgical site infections continue to represent a costly complication of spine surgery. Studies show that surgical smoke can contain infectious agents, and smoke evacuation systems have demonstrated effective removal of these particles from the operative field.

Methods: This study was a retrospective cohort analysis of surgical cases performed at two high-volume medical centers by three surgeons. Demographic and perioperative data were prospectively collected using the Spine AdVerse Events Severity (SAVES) system. The surgical invasiveness index and Charlson comorbidity score were calculated for each case. The incidence of SSIs in a cohort of surgical cases involving a smoke evacuator device was compared to a cohort that excluded the device. Statistical analyses were conducted to assess the relationship between patient and surgery characteristics and the wound infection outcome in relation to use of a surgical smoke evacuation system.

Results: 1312 spine surgery cases were included in the study. Of the 712 cases in the control group, 24 SSIs occurred (11 deep, 13 superficial), for an overall incidence of $3.4 \%$. Of the 600 cases in the smoke evacuator group, 12 SSIs occurred (8 deep, 4 superficial), for an overall incidence of $2 \%$. The observed difference in SSI incidence was not statistically significant $(p=0.17)$. The odds ratio for developing SSI calculated for the smoke evacuator group compared to the control group was 0.56 (95\% CI 0.28-1.14).
\end{abstract}

Discussion: This study represents an important first attempt at characterizing a previously unidentified, modifiable risk factor to consider in future studies of infection rates after spine surgery.

\section{Introduction}

It is estimated that 158,000 surgical site infections (SSIs) occur in the US annually and may cost up to $\$ 10$ billion [1-3]. In patients undergoing spine surgery, evidence suggests that factors such as diabetes, obesity, chronic steroid use, smoking, previous SSI, multiple vertebral levels, longer surgeries and increasing age, among others, are associated with an increased risk for surgical site infections [4-8]. The prevalence of SSIs in this patient population is thought to be between 0.7 and $15 \%$, with averages between 3 and 5\% [5-10].

Surgical smoke, also known as smoke plume or aerosol, refers to the suspension of particles in a gas created by electrosurgical, ultrasonic, and laser instruments in the operating room [11]. It has been well established in the medical literature that surgical smoke contains a number of potentially harmful components, including hazardous chemicals, tumor cells, and infectious agents. Lowtemperature vapor from an ultrasonic scalpel is more likely to carry large and viable infectious particles, while higher-temperature laser and electrocautery smoke produces smaller particles that tend to be more chemically hazardous [12-18]. Additionally, smoke has a noxious odor and decreases the visibility of the surgical field [19]. OSHA states that 500,000 workers are exposed to surgical smoke every year, but this federal agency does not specifically require the use of smoke evacuation and filtration systems [20,21]. This is likely because many of the effects are subtle and not immediate [18].
Plenty of evidence exists for the danger that surgical smoke poses to operating room personnel, including viral infection or exposure to carcinogens. There is less literature studying any effects of the smoke on patients. The present study is unique in its aim to quantify the risk of surgical smoke to patients undergoing spine surgery. Specifically, the study addresses the incidence of SSIs in a cohort of surgical cases involving a smoke evacuator device compared to a cohort that excluded the device. We hypothesized that use of a smoke evacuator device during spine surgery would reduce the number of surgical site infections. The purpose of this study was two-fold: to review the literature on the topic of surgical smoke and conduct an initial feasibility study to detect whether the use of a smoke evacuation system can effectively decrease the rate of SSI in spine surgery.

Correspondence to: Christian DiPaola, Department of Orthopedics \& Rehabilitation, University of Massachusetts Medical School, Worcester, MA, USA, Tel: 508-334-8119, Fax: 508-334-6052, E-mail: Christian.DiPaola@ umassmemorial.org

Key words: smoke evacuation, spine surgery, surgical site infections, surgical smoke Received: March 05, 2018; Accepted: April 05, 2018; Published: April 09, 2018 


\section{Methods}

This study was an IRB-approved retrospective cohort analysis of surgical cases performed at two high-volume medical centers by three surgeons. Two of the surgeons operated at one hospital while the third surgeon operated at another hospital. One surgeon from each hospital incorporated the smoke evacuator device into the operating room and therefore contributed both intervention and control cases. The third surgeon never used the device and therefore only contributed control cases. Similar ventilation systems were used in all operating rooms. All surgeons had at least five years of experience at the start of the collection period. Control cases occurred from January 2012 to June 2014. Intervention cases occurred from June 2014 to July 2016. The data was prospectively collected using the Spine AdVerse Events Severity (SAVES) system, which has been previously validated [22].

The device used in this study was the miniSQUAIR Smoke Evacuation System (Nascent Surgical, LLC, Eden Prairie, MN) [23]. Per the manufacturer's instructions for use, the disposable device was placed adjacent to the incision prior to each operation $[12,13,20,24]$. In total, 1312 consecutive spine surgery cases were studied, including 600 cases using the smoke evacuator and 712 cases without use of the device.

The following patient characteristics were collected for each surgical case in the two cohorts: gender, age, surgeon, date of surgery, type of surgery (elective versus emergency), subtype of surgery (degenerative, trauma, infection, oncology, other), spinal region (cervical, thoracic, lumbar, sacral), presence of a device such as spinal instrumentation, $\mathrm{BMI}$, and the presence of COPD/asthma, HTN, renal conditions, existing neoplasm, anemia, diabetes, CHF, past cardiac complications, past spine surgery, and smoking status. The surgical invasiveness index was calculated for each case to describe the extent of the surgical intervention [25]. A broad range of pathologies was represented in each study arm, as well as both instrumented and non-instrumented surgical cases. The Charlson comorbidity index was calculated for each patient and used as a validated method of evaluating risk of death from comorbid disease [26]. For each surgery, a dichotomous variable indicating the presence or absence of a superficial and/or deep wound infection was calculated to serve as the primary outcome in the analysis. In addition to calculating descriptive statistics, bivariate analyses were conducted as appropriate (Chi-Square or t-tests) to assess the relationship between patient and surgery characteristics and the wound infection outcome. Variables that were found to be the most significantly related at the bivariate level were entered into a logistic regression to determine key predictors in wound infections.

\section{Results}

A total of 1312 spine surgery cases were included in the study: 600 intervention cases and 712 controls. Descriptive statistics for each cohort are listed in table 1. A formal analysis of group differences was not performed because none of the patient factors were found to significantly impact the primary outcome. The primary outcome data is listed in table 2. In the control group, 24 surgical site infections occurred (11 deep wound infections, 13 superficial wound infections), for an overall incidence of $3.4 \%$. In the smoke evacuator group, 12 surgical site infections occurred ( 8 deep wound infections, 4 superficial wound infections), for an overall incidence of $2 \%$. The observed difference in SSI incidence between the groups was not statistically significant $(p=0.17)$.

There were no significant differences in the incidence of SSI between the three surgeons involved in the study. The average surgical invasiveness index (SII) for those cases that resulted in a surgical site
Table 1. Descriptive statistics.

\begin{tabular}{|c|c|c|c|c|}
\hline Variable & $\begin{array}{c}\text { Smoke } \\
\text { Evacuator } \\
\text { Group }\end{array}$ & $\%$ of total & $\begin{array}{l}\text { Control } \\
\text { Group }\end{array}$ & $\%$ of total \\
\hline Total Subjects & 600 & & 712 & \\
\hline Male & 311 & $52 \%$ & 361 & $51 \%$ \\
\hline Female & 289 & $48 \%$ & 351 & $49 \%$ \\
\hline Age & $55.36(17-92)$ & & $55.42(19-95)$ & \\
\hline Elective surgery & 578 & $96 \%$ & 688 & $97 \%$ \\
\hline Emergency surgery & 22 & $4 \%$ & 24 & $3 \%$ \\
\hline Instrumentation & 81 & $14 \%$ & 172 & $24 \%$ \\
\hline \multicolumn{5}{|l|}{ Region of spine involved } \\
\hline Cervical & 150 & $25 \%$ & 171 & $24 \%$ \\
\hline Thoracic & 93 & $16 \%$ & 85 & $12 \%$ \\
\hline Lumbar & 415 & $69 \%$ & 499 & $70 \%$ \\
\hline Sacral & 165 & $28 \%$ & 225 & $32 \%$ \\
\hline BMI & $\begin{array}{c}30.54(17.1- \\
71.2)\end{array}$ & & $\begin{array}{c}31.25(17.9- \\
52.7)\end{array}$ & \\
\hline $\begin{array}{l}\text { Total surgical site } \\
\text { infections }\end{array}$ & 12 & $2 \%$ & 24 & $3 \%$ \\
\hline Deep wound infections & 8 & $1 \%$ & 11 & $2 \%$ \\
\hline $\begin{array}{l}\text { Superficial wound } \\
\text { infections }\end{array}$ & 4 & $1 \%$ & 13 & $2 \%$ \\
\hline \multicolumn{5}{|l|}{ Comorbidities } \\
\hline COPD & 14 & $2 \%$ & 39 & $5 \%$ \\
\hline Asthma & 40 & $7 \%$ & 52 & $7 \%$ \\
\hline HTN & 206 & $34 \%$ & 245 & $34 \%$ \\
\hline Diabetes & 94 & $16 \%$ & 93 & $13 \%$ \\
\hline Past spine surgery & 198 & $33 \%$ & 216 & $30 \%$ \\
\hline Current smoking history & 207 & $35 \%$ & 207 & $29 \%$ \\
\hline Former smoking history & 129 & $22 \%$ & 102 & $14 \%$ \\
\hline $\begin{array}{l}\text { Avg Charlson Comorbidity } \\
\text { Score }\end{array}$ & 0.97 & & 0.72 & \\
\hline $\begin{array}{l}\text { Avg Surgical Invasiveness } \\
\text { Index }\end{array}$ & 6.18 & & 5.15 & \\
\hline
\end{tabular}

Table 2. Surgical site infections.

\begin{tabular}{|c|c|c|c|c|}
\hline Group & $\begin{array}{c}\text { Superficial SSI } \\
(\mathbf{\%})\end{array}$ & Deep SSI (\%) & All SSI (\%) & Total \# Patients \\
\hline $\begin{array}{c}\text { Smoke } \\
\text { Evacuator }\end{array}$ & $4(0.67)$ & $8(1.33)$ & $12(2.00)$ & 600 \\
\hline Control & $13(1.83)$ & $11(1.54)$ & $24(3.37)$ & 712 \\
\hline Combined & 17 & 19 & 36 & 1312 \\
\hline
\end{tabular}

infection was 7.8 (95\% CI 5.7-9.6), while the average SII for the noninfections was 6.3 (95\% CI 6.0-6.6), but the difference between the two groups did not achieve statistical significance. Of the 36 documented surgical site infections, 27 (75\%) involved instrumentation. Six (16.7\%) of the SSIs occurred with an emergency procedure, whereas $40(3.1 \%)$ of the non-infections were emergency surgical cases, which represented a statistically significant difference $(p<0.001)$.

The cervical spine was involved in 11 SSIs, the thoracic spine in 11 SSIs, the lumbar spine in 23 SSIs, and the sacral spine in 8 SSIs. Our analysis was likely insufficiently powered to find statistically significant associations between SSI and gender, age, Charlson comorbidity score, COPD, asthma, renal conditions, presence of neoplasm, anemia, CHF, smoking history, past cardiac complications, or past spine surgery. Diabetes was present in 9 (25\%) SSI cases and 178 (14\%) non-infection cases, and the difference between the two groups approached but did not achieve statistical significance $(p=0.085)$.

A logistic regression analysis was run to isolate the effects of the smoke evacuator device, SII, and diabetes on the infection outcome. The results are displayed in table 3 . When all other variables were held 
Table 3. Logistic regression analysis with adjusted adds ratio estimates.

\begin{tabular}{|c|c|c|}
\hline Variable & Adjusted OR [95\% CI] & p -value \\
\hline Smoke evacuator vs. none & $0.563[0.278-1.138]$ & 0.1097 \\
\hline Surgical invasiveness index & $1.050[0.992-1.112]$ & 0.0918 \\
\hline Diabetes absent vs. present & $0.487[0.224-1.056]$ & 0.0686 \\
\hline
\end{tabular}

constant, the adjusted odds ratio for developing SSI calculated for the smoke evacuator group compared to the control group was $0.56(95 \%$ CI 0.28-1.14). The likelihood of infection appears to decrease slightly with the addition of the smoke evacuator, but not significantly $(p=$ 0.11 ). As the invasiveness of the surgery increases by one unit on the SII, the risk of infection seems to increase slightly by an odds ratio of 1.05 (95\% CI 0.99-1.11, $p=0.09$ ). Finally, the absence of diabetes was found to have an odds ratio of 0.49 for developing a SSI as compared to the presence of diabetes (95\% CI 0.22-1.06, $p=0.069$ ).

\section{Discussion}

Our results did not show a statistically significant decrease in the rate of SSI after introduction of the smoke evacuator device. However, this study represents an important first attempt at characterizing a previously unidentified, modifiable risk factor to consider in future studies of infection rates after spine surgery.

Our results suggest that diabetes is a risk factor for SSI, which has been previously demonstrated in the literature [5-9]. Importantly, diabetes is an essentially fixed variable once the patient enters the operating room. In order to decrease the surgical site infection rate, we must continue to explore and eliminate modifiable risk factors. The literature suggests that surgical smoke potentially represents one such factor.

There have been several studies demonstrating the presence of viruses in surgical smoke such as the Human Papilloma Virus (HPV) [13,27-29] and Human Immunodeficiency Virus (HIV) [18,30-32]. One surgeon developed laryngeal papillomatosis after operating on a patient's anogenital condyloma with the same HPV serotypes, supporting the idea that aerosolized infectious particles can be transmitted through the surgical plume [33]. Viable erythrocytes and blood products in the smoke also suggest its infectious potential $[34,35]$. It has been shown that bacteria can be cultured from surgical smoke [36-38]. Studies have demonstrated that hydrodynamic pulsatile debridement of wounds led to bacterial aerosolization, and inadequate operating room air removal procedures likely contributed to a nosocomial outbreak of a multi-drug resistant bacterial infection [39-44]. Furthermore, Schultz demonstrated that use of a localized smoke evacuation system limited the aerosolization of bacteria under laboratory conditions with $99.5 \%$ efficiency [45].

Based on the basic science data and case reports highlighting the infectious potential of surgical smoke, as well as data showing the effectiveness of the device at clearing the air of most harmful particles, we felt it was a logical next step to study the clinical benefit of surgical smoke evacuation. While we were unable to show a significant difference in the rate of SSI in the study group compared to a control group, our study marks an important first step in the discovery of a potential risk factor that can be easily eliminated to decrease a patient's risk of developing a surgical site infection.

Our study was limited by a lack of sufficient power to detect differences in the incidence of SSI given the low baseline prevalence of this adverse event. Furthermore, any differences may have been confounded by the use of local vancomycin powder, which was introduced into the surgeons' operating rooms on nearly the same date as the smoke evacuator device (used equally in all operating rooms). Future studies will need a much larger sample size and either an avoidance or equal distribution of antibiotic substances in the two study arms in order to detect a statistically and clinically significant difference in SSI rates with the use of a smoke evacuator. There were additional comorbidities omitted from our study, such as nasopharyngeal colonization of Staphylococcus aureus. However, all study patients went through a decontamination process, were tested preoperatively for bacterial colonization, and given appropriate intranasal antibiotic treatment. We used the Charlson comorbidity index to account for general medical frailty, but the utilization of this classification system inevitably removes a certain level of detail from the data.

There are many advantages to removing surgical smoke from the operative field irrespective of its infectious potential. Surgical smoke creates a serious occupational hazard. It has been found to contain hydrogen cyanide, butadiene, acetylene, benzene, acrolein, ammonia, formaldehyde, and more [24,46-48]. It is thought that benzene is a main player in carcinogenesis [18]. One study demonstrated that chemicals in the smoke generated from breast reduction surgery were mutagenic on a strain of DNA in a Salmonella model $[46,47]$. Another group studied the effect of surgical smoke on rat lung parenchyma, noting blood vessel hypertrophy, alveolar congestion, and emphysematous changes in the lungs of exposed animals [24]. Many argue that chronic exposure to surgical smoke represents a risk similar to inhaling secondhand cigarette smoke. According to the results of one study, thermal destruction of one gram of tissue by electrocautery has a mutagenicity equivalent to six cigarettes $[12,48,49]$. Surgical smoke may also carry malignant cells depending on the tissue being ablated, which could have implications for the presence of port-site metastases in laparoscopic colon tumor resection surgeries [34,50-54]. Additionally, our surgeons reported that the device removed vaporized bone from the field, which represents a technical advantage while operating.

Surgical site infection continues to represent a costly burden to the healthcare system. One study demonstrated that the introduction of an infection prevention bundle reduced the risk of SSI from $4 \%$ to $2 \%$ and led to an average cost savings of approximately $\$ 866$ per patient [1]. That study quoted a median infection-specific cost of $\$ 25,962$ per SSI [1]. Using this figure along with the cost of the smoke evacuator device used in the present study ( $\$ 19$ per case), the device would need to prevent just 1 infection out of 1366 surgical cases to pay for itself. As part of the routine surveillance of adverse events in spine surgery, we strongly suggest that surgical smoke evacuation continues to be studied as a variable that may have an association with SSI in spinal surgery.

\section{Author contributions}

Each author contributed equally to the design, development, writing, and editing of the manuscript.

\section{Funding sources}

Self-funded

\section{Conflict of interest}

Dr. DiPaola receives royalty payments from K2M.

\section{References}

1. Featherall J, Miller JA, Bennett EE, Lubelski D, Wang H, et al. (2016) Implementation of an Infection Prevention Bundle to Reduce Surgical Site Infections and Cost Following Spine Surgery. JAMA Surg 151: 988-990. [Crossref] 
2. Magill SS, Edwards JR, Bamberg W, Beldavs ZG, Dumyati G, et al. (2014) Multistate point-prevalence survey of health care-associated infections. N Engl J Med 370: 11981208. [Crossref]

3. Scott RDI (2009) The Direct Medical Costs of Healthcare-Associated Infections in US Hospitals and the Benefits of Prevention. Atlanta, GA: Centers for Disease Control and Prevention.

4. Atkinson RA, Stephenson J, Jones A, Ousey KJ (2016) An assessment of key risk factors for surgical site infection in patients undergoing surgery for spinal metastases. $J$ Wound Care 25: S30-34. [Crossref]

5. Pull ter Gunne AF, Cohen DB (2009) Incidence, prevalence, and analysis of risk factors for surgical site infection following adult spinal surgery. Spine (Phila Pa 1976) 34 1422-1428. [Crossref]

6. De la Garza-Ramos R, Abt NB, Kerezoudis P, McCutcheon BA, Bydon A, et al. (2006) Deep-wound and organ-space infection after surgery for degenerative spine disease: an analysis from 2006 to 2012. Neurol Res 38: 117-123. [Crossref]

7. Meng F, Cao J, Meng X (2015) Risk factors for surgical site infections following spinal surgery. J Clin Neurosci 22: 1862-1866. [Crossref]

8. Caputo AM, Dobbertien RP, Ferranti JM, Brown CR, Michael KW, et al. (2013) Risk factors for infection after orthopaedic spine surgery at a high-volume institution. $J$ Surg Orthop Adv. 22: 295-298. [Crossref]

9. Klemencsics I, Lazary A, Szoverfi Z, Bozsodi A, Eltes P, et al. Risk factors for surgical site infection in elective routine degenerative lumbar surgeries. Spine J 16: 1377-1383. [Crossref]

10. Kumar K, Crawford AH (2002) Role of "Bovie" in spinal surgery: historical and analytical perspective. Spine (Phila Pa 1976) 27: 1000-1006. [Crossref]

11. Bigony L (2007) Risks associated with exposure to surgical smoke plume: a review of the literature. AORN J 86: 1013-1020. [Crossref]

12. Alp E, Bijl D, Bleichrodt RP, Hansson B, Voss A (2006) Surgical smoke and infection control. J Hosp Infect 62: 1-5. [Crossref]

13. Garden JM, O'Banion MK, Shelnitz LS, Pinski KS, Bakus AD, et al. (1988) Papillomavirus in the vapor of carbon dioxide laser-treated verrucae. JAMA 259: 11991202. [Crossref]

14. Wisniewski PM, Warhol MJ, Rando RF, Sedlacek TV, Kemp JE, et al. (1990) Studies on the transmission of viral disease via the $\mathrm{CO} 2$ laser plume and ejecta. $J$ Reprod Med 35: 1117-1123. [Crossref]

15. Ott DE, Moss E, Martinez K (1998) Aerosol exposure from an ultrasonically activated (Harmonic) device. J Am Assoc Gynecol Laparosc 5: 29-32. [Crossref]

16. Nezhat C, Winer WK, Nezhat F, Nezhat C, Forrest D, et al. (1987) Smoke from laser surgery: is there a health hazard? Lasers Surg Med 7: 376-382. [Crossref]

17. Heinsohn P, Jewett DL, Balzer L, Bennett CH, Seipel P, et al. (1991) Aerosols created by some surgical power tools: particle size distribution and qualitative hemoglobin content. App Occup Environ Hyg 6: 773- 776.

18. Barrett WL, Garber SM (2003) Surgical smoke: a review of the literature. Is this just a lot of hot air? Surg Endosc 17:979-987. [Crossref]

19. Weld KJ, Dryer S, Ames CD, Cho K, Hogan C, et al. (2007) Analysis of surgical smoke produced by various energy-based instruments and effect on laparoscopic visibility. $J$ Endourol 21: 347-351. [Crossref]

20. (1988) OSHA. National Institute for Occupational Safety and Health hazard evaluation report 88-126-1932. Washington: National Institute for Occupational Safety and Health.

21. (1996) OSHA. Control of smoke from laser/electric surgical procedures. Publication 96-128. Washington: National Institute for Occupational Safety and Health.

22. Street JT, Lenehan BJ, DiPaola CP, Boyd MD, Kwon BK, et al. (2012) Morbidity and mortality of major adult spinal surgery. A prospective cohort analysis of 942 consecutive patients. Spine J 12: 22-34. [Crossref]

23. Schultz L (2014) An analysis of surgical smoke plume components, capture, and evacuation. AORN J 99: 289-298. [Crossref]

24. Wenig BL, Stenson KM, Wenig BM, Tracey D (1993) Effects of plume produced by the Nd:YAG laser and electrocautery on the respiratory system. Lasers Surg Med 13: 242-245. [Crossref]

25. Mirza SK, Deyo RA, Heagerty PJ, Konodi MA, Lee LA, et al. (2008) Development of an index to characterize the "invasiveness" of spine surgery: validation by comparison to blood loss and operative time. Spine (Phila Pa 1976) 33: 2651-2661. [Crossref]
26. Charlson ME, Pompei P, Ales KL, MacKenzie CR (1987) A new method of classifying prognostic comorbidity in longitudinal studies: development and validation. $J$ Chronic Dis 40: 373-383. [Crossref]

27. Garden JM, O’Banion MK, Bakus AD, Olson C (2002) Viral disease transmitted by laser-generated plume (aerosol). Arch Dermatol 138: 1303-1307. [Crossref]

28. Sawchuk WS, Weber PJ, Lowy DR, Dzubow LM (1989) Infectious papillomavirus in the vapor of warts treated with carbon dioxide laser or electrocoagulation: detection and protection. J Am Acad Dermatol. 21: 41-49. [Crossref]

29. Gloster HM, Roenigk RK (1995) Risk of acquiring human papillomavirus from the plume produced by the carbon dioxide laser in the treatment of warts. $J$ Am Acad Dermatol 32: 436-441. [Crossref]

30. Baggish MS, Poiesz BJ, Joret D, Williamson P, Refai A (1991) Presence of human immunodeficiency virus DNA in laser smoke. Lasers Surg Med 11: 197-203. [Crossref]

31. DesCoteaux JG, Picard P, Poulin EC, Baril M (1996) Preliminary study of electrocautery smoke particles produced in vitro and during laparoscopic procedures. Surg Endosc 10:152-158. [Crossref]

32. Johnson GK, Robinson WS (1991) Human immunodeficiency virus-1 (HIV-1) in the vapors of surgical power instruments. J Med Virol 33: 47-50. [Crossref]

33. Hallmo P, Naess O (1991) Laryngeal papillomatosis with human papillomavirus DNA contracted by a laser surgeon. Eur Arch Otorhinolaryngol 248: 425-427. [Crossref]

34. Fletcher JN, Mew D, DesCoteaux JG (199) Dissemination of melanoma cells within electrocautery plume. Am J Surg 178: 57-59. [Crossref]

35. Jewett DL, Heinsohn P, Bennett C, Rosen A, Neuilly C (1992) Blood-containing aerosols generated by surgical techniques: a possible infectious hazard. Am Ind Hyg Assoc J 53: 228-231. [Crossref]

36. Byrne PO, Sisson PR, Oliver PD, Ingham HR (1987) Carbon dioxide laser irradiation of bacterial targets in vitro. J Hosp Infect 9: 265-273. [Crossref]

37. Mullarky MB, Norris CW, Goldberg ID (1985) The efficacy of the CO2 laser in the sterilization of skin seeded with bacteria: survival at the skin surface and in the plume emissions. Laryngoscope 95: 186-187. [Crossref]

38. Capizzi PJ, Clay RP, Battey MJ (1998) Microbiologic activity in laser resurfacing plume and debris. Lasers Surg Med 23: 172-174. [Crossref]

39. Sonnergren HH, Polesie S, Strombeck L, Aldenborg F, Johansson BR, et al. (2015) Bacteria aerosol spread and wound bacteria reduction with different methods for wound debridement in an animal model. Acta Derm Venereol 95:272-277. [Crossref]

40. Sonnergren HH, Strombeck L, Aldenborg F, Faergemann J (2013) Aerosolized spread of bacteria and reduction of bacterial wound contamination with three different methods of surgical wound debridement: a pilot study. J Hosp Infect 85: 112-117. [Crossref]

41. Maragakis LL, Cosgrove SE, Song X, Kim D, Rosenbaum P, et al. (2004) An outbreak of multidrug-resistant Acinetobacter baumannii associated with pulsatile lavage wound treatment. JAMA 292: 3006-3011. [Crossref]

42. Loehne HB, Streed SA, Gaither B, Sherertz RJ (2002) Aerosolization of microorganism during pulsatile lavage with suction. Abstract presented at: Symposium on Advanced Wound Care and Medical Research Forum on Wound Repair; Baltimore.

43. Daeschlein G, Lehnert W, Arnold A, Haase H, Junger M (2010) Hygienic safety of a new hydrodynamic wound debridement system. Dermatol Surg 36: 1426-1438. [Crossref]

44. Angobaldo J, Marks M (2008) Prevention of projectile and aerosol contamination during pulsatile lavage irrigation using a wound irrigation bag. Wounds 20: 167-170. [Crossref]

45. Schultz L (2015) Can Efficient Smoke Evacuation Limit Aerosolization of Bacteria? AORN J. 102: 7-14. [Crossref]

46. Gatti JE, Murphy B, Noone RB, Murphy JB (1986) Analysis of electrocautery smoke produced during reduction mammoplasty. Surg Forum 37: 579-580. [Crossref]

47. Gatti JE, Bryant CJ, Noone RB, Murphy JB (1992) The mutagenicity of electrocautery smoke. Plast Reconstr Surg 89: 781-784. [Crossref]

48. Moot AR, Ledingham KM, Wilson PF, Senthilmohan ST, Lewis DR, et al. (2007) Composition of volatile organic compounds in diathermy plume as detected by selected ion flow tube mass spectrometry. ANZ J Surg 77: 20-23. [Crossref]

49. Tomita Y, Mihashi S, Nagata K, Ueda S, Fujiki M, et al. (1981) Mutagenicity of smoke condensates induced by $\mathrm{CO} 2$-laser irradiation and electrocauterization. Mutat Res 89 : 145-149. [Crossref] 
50. Cavina E, Goletti O, Molea N, Buccianti P, Chiarugi M, et al. (1998) Trocar site tumor recurrences. May pneumoperitoneum be responsible? Surg Endosc 12: 1294-1296. [Crossref]

51. Ikramuddin S, Lucus J, Ellison EC, Schirmer WJ, Melvin WS. Detection of aerosolized cells during carbon dioxide laparoscopy. J Gastrointest Surg 2: 580-583. [Crossref]

52. Reymond MA, Schneider C, Kastl S, Hohenberger W, Kockerling F (1998) The pathogenesis of port-site recurrences. J Gastrointest Surg 2: 406-414. [Crossref]
53. Tseng LN, Berends FJ, Wittich P, Bouvy ND, Marquet RL, et al. (1998) Port-site metastases. Impact of local tissue trauma and gas leakage. Surg Endosc 12: 1377-1380. [Crossref]

54. Nduka CC, Poland N, Kennedy M, Dye J, Darzi A (1998) Does the ultrasonically activated scalpel release viable airborne cancer cells? Surg Endosc 12: 1031-1034. [Crossref]

Copyright: (C2018 Krueger S. This is an open-access article distributed under the terms of the Creative Commons Attribution License, which permits unrestricted use, distribution, and reproduction in any medium, provided the original author and source are credited. 